\title{
Amalgamation, The Centenary of Chancy Business: Nigeria Through Evasive Unity
}

\author{
Ghazali Bello Abubakar* \\ Department of Political Science, Sokoto State University, Nigeria
}

Submission: July 20, 2018; Published: September 04, 2018

"Corresponding author: Ghazali Bello Abubakar,Department of Political Science, Sokoto State University, Sokoto, Tel: +234(0)7033164828;

Email: alghazel@gmail.com

\begin{abstract}
North and South regions altogether form what emerged as modern day's Nigeria. The nation that comes to being through the joining of the two protectorates by the British Governor-General, Lord Lugard had since, served a miracle especially for the British Empire simply because it had eased administration among the two disparately different societies whose disunity converted into a future populous nation in Africa known Nigeria. This paper investigated the outcomes of the 1914 marriage between North and South. It has tried to however, explore the factors that attracted the very assemblage between the two regions. The paper however, proposed to investigate the causes that are responsible for stagnation and backwardness throughout modern history of Nigeria. It has nevertheless, explored that the interconnectivity between North and South was merely imperialists' intention; it therefore, fails to address the key issues disturbing this chance of being together. Dominantly, the widely spoken languages are Hausa, Yoruba and Igbo.
\end{abstract}

Keywords: Chancy business;Engagement;North-South;Traditional differences;Unity andDiversity

\section{Introduction}

Nigeria was colonized by the British Empire in the late nineteenth century as two regions: South and North protectorates that are equally divided along religious and tribal lines. The political independence was achieved on 1st October 1960, likewise many African countries. These two dominantly disparate regions were ideally in need with different strategy before it become possible to proceed in controlling them as single entity known later Nigeria. Dissimilarities never limited on historical background, but extended to orientation, tradition and culture, and to physical appearance as well. Consequently, in the aftermath of the independence, the feeling of belonging and patriotism was not so popular among Nigerians [1].It was not in the plan to acquire more land in West Africa after Lagos, which had during those days served as sea-border used to safeguard Royal Commercial Interest was captured [2].

North and southern Nigeria are disparately dissimilar and equally divided along ethnic identity and religious sentimentalism. In pre-colonial Nigeria, the two regions were not in touch. Rather, the colonial masters set them united through the means of amalgamation for merely cushy access and control. Hence, it was not appeared to safeguard Nigeria's solidarity. Perhaps it was all about ensuring cheap administration and easy use of both human and natural resources available in the areas[1]. Upon amalgamation, several important factors were not being taken into consideration, and perhaps, that could have relation with the future difficulties of the country. Prior to the plan that brought about the united Nigeria and otherwise known as amalgamation popularly; cultural adherences, history and background were not being put into consideration. Above all, the two Abrahamic faiths namely: Islam and Christianity[3]. those predominantly remain symbols for North and South respectively, are artificially neutralized from their cultures and traditions overnight to satisfy the ostensible unity and conglomeration.

Notwithstanding all accomplished by the British colonial imperialists to ensure a concrete bridge that could permanently cement North and South, the regional intermarriage according to Momah.inculcates stagnation and severe economic condition, especially the one of 1980s. This interconnectivity between the two asymmetrical sides has been able to realize independent Nigeria by 1960 . Six years since independence when the first bloodbath was witnessed in the history of modern Nigeria. That strife has been in the position to play a defeatist role in galvanizing political and socio-tribal crises in the country over the course of assassination[3]. The strife soon turned to endemic civil war that has epidemically caused loss of hundreds of lives of innocent Nigerians. This civil ferment shadowed the entire nation for almost 36 months' time. The state of anarchic bedlam over the courses of why assassination and how administrative structure of this new-born nation supposed to come to light, become a perplex between Hausa/Fulani in the Muslim 
predominant north, the region that lost the number one figure in the nation, Sir Abubakar Tafawa Balewa, first and the only Prime Minister of Nigeria followed by the Premier of northern region, Sir Ahmad Bello, the Sardauna of Sokoto in 1966[4].

An Igbo man and senior military officer in Nigerian Army, Major-General Johnson Aguiyi Ironsi, had quickly climbed to the highest office in the country after the January 1966 coup. Ironsi took advantage of the chaotic havoc and seized the power. This makes him the second person to lead Nigeria after Balewa. Still that was not end of the story rather; it marked the starting point of the social mistrust, political brinkmanship and even economic and financial crises in Nigeria until today. As much of the coup planners were Igbos from the east, Hausas from the north managed to consider the opportune incidence as a plan to ruin down their stance in the country's widely central administration. Hence, the northern military officers therein saw reprisal as inevitable as admissible. On $29^{\text {th }} J$ uly 1966 Ironsi was killed by northern military officers in what they called "July counter coup". This incidence had circuitously paved the way for Major-General Yakubu Gowon, a young army officer from the north to take over the country for another long uninterrupted eight years.

\section{Conceptual Terminology}

As term, amalgamation refers to amplitude of meanings. In Cambridge Advanced Lerner's Dictionary ( $3^{\text {rd }}$ edn (2010), amalgamation comes to light "when separate organizations unite in order to form a large grouping body". For metallurgist, "it is the combination of two or more elements to form one unique element". Charles Beers III described amalgamation as "the process of combining or uniting multiple entities into one form; to mix or merge so as to make a combination, blend and unite" Beers[2]. The term according to Ikedikwa[5]. to amalgamate is to "fuse or merge two entities or bodies into one with the result that both will cease to exist and are replaced by the new body or entity". Amalgamation terminologically, is a concept that has championed popularity during the interregional marriage of unity. This centenary of union and its subsequent consequences are the central thesis of this study.

\section{Historical Overview}

Colonizing Nigeria was not result of merely British discovery of a land, but was also determination and vision, which were part of the forces strengthened British ambition in extending and bringing massive areas under their control. British reached the place known today Nigeria somewhere in the late $19^{\text {th }}$ century only to meet two disparate parts who are autonomously independent from one another ethnically, tribally and religiously. Northern and Southern regions that make future Nigeria have never demonstrated a symbol of homogeneity simply because their peoples and tribes are widely different. Regardless with these differences, for the sake of effective administration, the colonial masters therein decided to tighten the knot between North and South somewhere in 1914[6].
Obviously, mixture of variety of things of different shapes gives a wonderful combination. This is what was expected by North-South amalgamation too. Instead, division, rivalry and unnecessarily antagonism based on ethnicity or tribe soon overtake the newly innocent independent nation amidst national development. By now, it is exact one hundred years past on this historic (suppose) togetherness. But the atrocious detail is that, throughout this span of time, Nigeria as one country, has so far failed to prove any competitive progress. Thus, regional sense of belonging instead of patriotism takes advantage to bolster corruption, mismanagement and other malfeasances. Alternatively, good governance, rule of law and social development are overtaken by regional sentimentalism [7].

\section{Amalgamation: An Opportunity or a Chancy Business?}

In more than one nation colonized by the British Empire, single system was used to administer affairs and activities of the colonies. In Kenya, Ghana or even India for example, single system was used as control mechanism. In Nigeria the two asymmetric regions: South and North administered separately until 1914 that has played a significant role in bolstering the gap between the two regions. In historical tale of colonial legacies in Nigeria, Ibrahim Gambari [8]. observes that the colonial rule created some waves of challenges and burden especially in the post-independence Nigeria for nation-building. Colonial administration divided Nigeria into pieces of North and South with different land tenure, educational and judiciary systems as well as local government administration.

Most of the 1950s and 1960s Nigeria's elites had their education therefore, world outlook guided by regional institutions. Some had very little and or had no further understanding of their immediate region [8]. These together with the natural dissimilarities had easily made it possible for hateful disdain, fear and prejudice to prevail. Even during the struggle of independence, Nigerian nationalists were regionalists; never they were united neither had a single ambition. Of course, they were striving to achieve the prime goal of freedom out of the colonial bondage, simultaneously, were fighting based on the broadly different regions they came from as much as their fighting against imperialists. Throughout decolonization process, Nigeria proved to have a very peculiar attribute. India, Ghana, South Africa and Tanzania won their independence through centrally rallying figures like Mahatma Gandhi, Kwame Nkrumah, Nelson Mandela and Julius Nyerere. Whereupon in the case of Nigeria, each of its three main regions namely: east, north and west sent its representative. Nmandi Azikiwe represented east, Sir Ahmad Bello north, and Obafemi Awolowo west. This is how Nigeria gained independence. This genesis until today makes nation-building in Nigeria virtually seldom in nature. It was very fortunate that the nation wasn't seized to exist, had also never succumbed to the given challenges [8]. 
The founding fathers therein, adopted a system that could better suit the natural being of the nation. That was federalism so that the united Nigeria can be maintained through diversified and inevitable regional and tribal differences. Sadly, the absence of integrity among the two sides to maintain the policy advocated and federalism adopted during the post-independence era, soared the famous civil strife in 1960s which soon transformed to historic civil war in the country [8].The civil atrocity becomes a mirror through which the entire Nigerian societies exist within the boundaries of three zones use to calculate how to present their stake to the central government economically politically and socially. In fact, the interest of the region or zone is prioritized than the Nigeria's group of interests as a nation. Therefore, for the sake of place of birth whether it is in the north, east or west could, at any given time, seize Nigeria's interest to be perused.

\section{Engagement as Factor of Entanglement}

Essentially, ever before the 1914, dissimilarities and even incomparability were playing palpable role in the then not yet connected regions. However, the major target of the imperialists while amalgamating the two sides was not favoring building a solid and stronger Nigeria, but a smooth governing, which served them much better than it served Nigerians. Hence, the policy of "divide and rule" was adopted deliberately. The colonial imperialists therefore, seized the chance to subjugate the local indigenous population and implant roots of mutilation in the future Nigeria [9]. To ensure this according to Salami [10]. the British established treaty with northern elders to create chances for them including political appointments and finally handover power through their men. In turn, the elders would protect the colonial interests especially the economic one [10].Northern region was feebly weak as it was suffering from insufficient welltrained indigenous manpower. This was the major rising issue that the premier of the region, Sir Ahmad Bello observed, and do believed that to fully utilize the independence obtained the problem of illiteracy must be addressed. Northern side with not sub-regional sectarianism had a crucial place and thus role to play in shaping the destiny of newly born nation, Nigeria, unlike south where the region is equally divided along tribal and linguistic lines: east and west (Igbo and Yoruba) Dan Agbese [6]. As far as the north is concerned, though zones are there but only to identify geo-political demarcation. Sir Ahmad Bello was, alone, the premier of the entire northern region while Azikiwe and Awolowo were the two champions representing east and west from the main south [11].

The premier of the northern region soon realized that the unity of entities in the north could not balance the advancement of large trained indigenous southerners, thus the next upcoming years must be extreme for the north until if solving strategies would be given chances otherwise, north will find itself in dilemma either depending on expatriates or face immediate collapse in case they shouldn't be able to produce enough manpower equivalent to their needs. The policy of indigenizing public service was introduced by East and West regions of the main South, which became mandatory for North to apply the same policy. This policy put public service under regional control. North, in facing the challenge of less and very limited manpower, compelled to hire expatriates from Egypt, Pakistan, India and Sri Lanka for professional activities such as pharmacists, doctors, and teachers who delivered their services in laboratories, hospitals and schools[6].

The first and foremost struggles carried out by the premier and his ministers were said to be all but soaring up north to balance south in different forms. He paid visitations to various secondary schools and delivered pep talk as well as alacrity of hopes that could be dashed only with young talents and welltrained students who carried along with them a sentimentalism of their region. It was encouragement to share with their stakes in armed forces, western education in general, and other competitive advantages that would mean and serve a lot in the central government. In the south or at least east and west were also doing their best to maintain the status and beyond. This kind of attitude ensures that regional interests oversize and or overpower national objectives[4]. Integrity of Nigeria supposed to be non-negotiable due to the element of benefits that could be achieved only in unity. Instead, over the time, the integration soared suspicious and mistrust among as many as 240 ethnic nationalities. As a result, conflicts and civil strife based on ethnoreligious border-line are taking place constantly. Incrementally, by 1998 , the only alternative seen to tailor the enlarged gap bridging off the differences was democracy; a system in which the entire citizens will be given chance to exercise their rights to cast their vote in universal franchise so to take part in the formation of newly elected government regardless with the region they come from[11].

In 1999 Nigeria once again, return to civilian governance with the aim that the tension would melt down as decisions will now onward be carried out on consensus basis by the constituent representatives in the National Assembly. Appointments and positions in the central government are divided by six geopolitical zones. Though, the Nigeria's constitution hasn't provided for such kind of dialysis. This policy, apart from being unconstitutional, it apprehensively galvanizes more tension that nowadays threatens the golden unity of the nation. At the top level, each step elite or elder one may do it seldom to serve the nation. Elites, either at the position of governor, senator, representative, minister, head of parastal, etc. or at some other highly political appointments at the federation; the prime concern is put on ethno-zonalism not competency, sincere and patriotism [11]. Ostensibly, during GoodLuck Ebele Jonathan's Administration, the northerners were allegedly censured of sponsoring Boko Haram insurgency so to destabilize the government led by Ijaw person from South-South geo-political zone. Niger Delta militants (Avengers), Biafra agitators and other similar groups who demonstrate their willingness to secession are plunged 
by southerners so that the government of Muhammad Buhari, one of the think tanks of the north, will remain inactive.This unintentionally and unanimously, set two sides to play Game Theory where two players are on the ground and each chooses to move rationally so to maximize its payoff.This theory according to Joshua S. Goldstein and Jon C. Pevehouse[12]. was first used extensively in International Relations during the 1950s and 1960s by IR scholars to explain the Soviet-U.S. nuclear warfare contingencies. Different kinds of situations are represented by different levels of games [12,13].

\section{Conclusion}

As a nation, through nation building Nigeria experience number of difficulties including the civil strife that engulfed in 1966. Besides, the then newly born sovereign nation faced what could be considered imaginary aspiration inspired not by the consent of the local populations from the two distinct entities, but by whatsoever interest of the imperialists. For the past of one hundred years of coexisting, there is no meaningful and or remarkable achievement that can be proved if Nigeria's (the country which is enjoying (supposed) swimming between natural and human resources) positional stance in the international and regional politics is observed. Since independence, Nigeria is constantly seen through rivalries and conflicts both religious and tribal ones over the course of the inevitable dissimilarities, which are there for identification not inferiority and or superiority. The same differences that threaten Nigeria's unity give shine to the United States of America. The great test of stamina is that Nigeria exists between the Sudan, Sahel Savanna and Rain Forest climate atmospheric zones. People from different customs, language, religions and independent ways of life i.e. Hausa, Igbo and Yoruba can make passion and dynamic expansion in progress and development.Together if handled with sincere is always strength, and therefore miraculously, produces beyond expectation.

\section{References}

1. Carland M (1985) The Colonial Office and Nigeria, 1898-1914, Hoover Institute Press, California, USA.

2. Beers Charles III (2014) Amalgamation, Library of Congress, Washington DC, USA.

3. Hughes W (2012) Abrahamic Religions, Oxford University Press, New York, USA.

4. Mbachu O (2011) Foreign Policy Analysis: The Nigerian Perspective, Joyce Publisher, Kaduna, Nigeria.

5. Ikedikwa C (2014) Amalgamation of Nigeria: Was it a mistake? Spectrum Book Ltd: Ibadan, Nigeria, West Africa.

6. Agbese Dan (2012) Ibrahim Babangida, the Military, Politics and Power in Nigeria, London Adonis and Abbey Publishers, London, England.

7. Olaniyan R (2003) The Amalgamation and its Enemies: An interpretive History of Modern Nigeria, Ile-Ife: Obafemi Awolowo University Press, Africa.

8. Gambari I (2008) The Challenge of Nation Building: A case of Nigeria, Ph.D. Thesis, Abuja: University of Abuja, Nigeria, West Africa.

9. Ajayi JF (1992, November 04) The National Question in Historical Perspective, The Guardian Newspaper England, London, p. 12.

10. Salami YK (2009) The Political Economy of Nigeria and the Continuing Agenda of Re-colonization: A Challenge for Critical Knowledge Production, Pan-African Studies 3 (3): 125-141.

11. Malachy CZ and Nwobi F (2014) Integration Policies as Structures of Disintegration: The Political Economy of Nationhood and Resource Control in Nigeria, Journal of African Studies and Development 6 (8): 149-151.

12. Goldstein S and Pevehouse Jon C (2009) International Relations, Dorling Kindersley, New Delhi, India.

13. Cambridge Advanced Lerner's Dictionary (2013) Advanced Lerner's Dictionary, University Press, Oxford, USA.

\begin{tabular}{l} 
Your next submission with Juniper Publishers \\
will reach you the below assets \\
- Quality Editorial service \\
- Swift Peer Review \\
- Reprints availability \\
- E-prints Service \\
- Manuscript Podcast for convenient understanding \\
- Global attainment for your research \\
- Manuscript accessibility in different formats \\
( Pdf, E-pub, Full Text, Audio) \\
- Unceasing customer service \\
Track the below URL for one-step submission \\
https://juniperpublishers.com/online-submission.php \\
\hline
\end{tabular}

